\title{
Public Historians in the Classroom
}

\section{Commentary}

This article explores school history as a site of public history. It will start with some observations of the important points raised by Zerwas and Carretero in this volume, about school history and its relationship to public history, and then consider these ideas in the context of an example from Australia, my own national context. It will conclude by considering some of the challenges facing history teacher education and its role in producing public historians for the classroom.

\section{Public History and the democratizing of historical discourse}

Zerwas provides a good overview of the emergence and transformation of the Public History field, characterising its early development as an attempt to democratise authorship of the past, allowing for voices beyond traditional authorities. Although he doesn't use the phrase, this can be articulated as an increasing respect for what has been called "history from below", 1 the articulation of history from the perspective of once silenced, or marginalised groups. In the context of schooling, this democratizing of historical discourse has been advocated as a didactic or pedagogic process that Giroux articulates as "the rewriting of history through the power of student voice", ${ }^{2}$ a project whose limits may relate precisely to: (1) whose voices are present in any one classroom; and (2) the capacity of the students to get beyond inherited discourses, or the "schematic narrative templates" 3 that mediate their interpretations of the past. This is not impossible, as the late Roger Simon argued, but neither is it easy to accomplish. ${ }^{4}$ The history

1 Jim Sharpe, "History from below,“ in New perspectives on historical writing, ed. Peter Burke (Cambridge, UK: Polity Press, 1991).

2 Henry Giroux, "Border pedagogy and the politics of postmodernism," in Postmodernism, postcolonialism and pedagogy, ed. Peter McLaren (Sydney: James Nicholas Publishers, 1995), 51.

3 James V. Wertsch, "Collective memory and narrative templates," Social Research: An International Quarterly, 75, no. 1 (2008), 133-156.

4 Roger I. Simon, The touch of the past: Remembrance, learning, and ethics (New York: Palgrave Macmillan, 2005).

2 Open Access. (C) 2018 Robert J. Parkes, published by De Gruyter. (ब) BY-NC-ND This work is licensed under the Creative Commons Attribution-NonCommercial-NoDerivatives 4.0 License. https://doi.org/10.1515/9783110466133-008 
competitions for German youth explored by Zerwas, arguably operate as a specific manifestation of one kind of this pedagogical approach to public history, and are certainly not unique to the German Federation. Such a history competition, Zerwas concludes, allow for the writing of social and micro histories on topics that would not otherwise have been considered within the media, school or academic research. Though he also notes that the trends evident in the competition reflected the contours of political progress and public interest. This is a point I will return to below in my exploration of pre-service History teachers as public historians.

In curricula materials and syllabus documents the same democratizing of public history phenomenon emerges wherever local authorities incorporate the histories of marginalised peoples into the national narratives being taught. Even with the strong presence of critical and feminist discourses during the 1960s and 1970s, it took until the early 1990s, on the back of the 1988 bicentennial of the nation, for the official curriculum in the Eastern states of Australia to register alternative interpretations of the nation's past. The emergence of Feminist and Indigenous historical perspectives, in the New South Wales curricula of the time, challenged the master narratives of 'famous men' and 'peaceful settlement'. ${ }^{5}$ It was this curricula shift, alongside a broader debate about Aboriginal land rights claims (historically enshrined as the High Court's Mabo and Wik decisions), which ignited significant public debate and ultimately erupted into what we today call Australia's 'History Wars' ${ }^{6}$

Underlying the history wars of the 1990s in Australia, was a concern with representations of the colonial past. ${ }^{7}$ As Carratero has cleverly suggested, history wars emerge from the collision of Romantic and Enlightenment views of the past. Carratero's articulation of the Romantic aligns well with Nietzsche's ${ }^{8}$ notion of the monumental and antiquarian forms of historical discourse. For

5 Robert J. Parkes, “Teaching History as historiography: Engaging narrative diversity in the curriculum," International Journal of Historical Learning, Teaching and Research 8, no. 2 (2009): 118-132.

6 Stuart Macintyre and Anna Clark, The history wars (Melbourne:Melbourne University Press, 2003).

Tony Taylor and Robert Guyver, eds. History wars in the classroom: Global perspectives (London: Information Age Publishing, 2011).

7 Robert J. Parkes, "Reading History curriculum as postcolonial text: Towards a curricular response to the history wars in Australia and beyond," Curriculum Inquiry 37, no. 4 (2007): 383-400.

8 Friederich Nietzsche, "On the uses and disadvantages of history for life," trans. R. J. Hollingdale, in Untimely meditations, ed. Daniel Breazeale (Cambridge: Cambridge University Press, 1874/1983). 
Nietzsche, monumental historical discourse arises when 'great events' and deeds of people in the past are venerated and serve as models for present action; while antiquarian historical discourse is evident when attempts are made to preserve the past as cultural heritage and a source of identity. With my colleague Heather Sharp, I have argued elsewhere that these forms of historical discourse reflect precisely Rüsen's ${ }^{9}$ notions of exemplary and traditional historical consciousness respectively. ${ }^{10}$ Alternatively, what Carratero refers to as an Enlightenment view of history aligns with what Nietzsche ${ }^{11}$ called critical historical discourse, in which the past is interrogated and challenged from the standpoint of present understandings. Reading Rüsen, ${ }^{12}$ this Enlightenment view is arguably divided across what he calls critical and genetic historical consciousness. The former is the analogue of Nietzsche's critical historical discourse, in which present perspective challenges constructions of the past. However, the latter is more clearly the adoption of a strongly defined temporal or developmental perspective. It reflects what Seixas ${ }^{13}$ defines as a disciplinary approach to the past. For Carratero, the defining feature of the Enlightenment approach to history is the application of historical thinking and historical method, or the disciplinary approach to the past. He recognises the Enlightenment approach as an increasingly dominant feature of school history education since the 1960s, an assessment that can also be observed in the history curricula of New South Wales, Australia. ${ }^{14}$

Carratero notes that the tensions that erupt between Romantic and Enlightenment notions of history - the result of their conflicting instructional goals - are often more evident in colonial and postcolonial history teaching. Certainly it is worth noting that others have demonstrated that this kind of conflict is evident not only within post-colonial states, but is a potential of any

9 Jörn Rüsen, History: Narration - interpretation - orientation (New York: Berghahn Books, 2005). 10 Robert J. Parkes and Heather Sharp, "Nietzschean perspectives on representations of national history in Australian school textbooks: What should we do with Gallipoli?," ENSAYOS: Revisita de la Facultad de Educación de Albacete 29, no.1 (2014).

11 Nietzsche, history for life.

12 Rüsen, History

13 Peter Seixas, "Schweigen! die Kinder! or does postmodern history have a place in the schools?," in Knowing, teaching, and learning history: National and international perspectives, eds. Peter N. Stearns, Peter Seixas, and Sam Wineburg (New York: New York University Press, 2000).

14 Robert J. Parkes and Debra Donnelly, "Changing conceptions of historical thinking in History education: An Australian case study,” Revista Tempo e Argumento, Florianópolis 6, no. 11 (2014): 113-136. 
post-conflict or multicultural society. ${ }^{15}$ Importantly, Carratero claims in his own national context, that history teaching aimed at getting students to love their Spanish country, has serious consequences for understanding Spain's colonial past. It is difficult to construct a narrative that invites students to fall in love with their nation, while simultaneously offering a critique of the traumas it has inflicted on the peoples of other nations, or marginalised groups within its own society. It is precisely this tension that saw the history wars erupt in Australia, when the historian Geoffrey Blainey ${ }^{16}$ lamented the teaching of what he labelled the 'black armband' or mournful view of Australia's past; and proclaimed the need to get the 'balance sheet' right. His arguments appealed to the conservative Howard government of the time, who were concerned by the emergence of Indigenous perspectives on the past which rejected the "great Australian silence" that had erased the violent conflicts of the colonial period from public memory. ${ }^{17}$

This debate over the national narrative focused on the curriculum as ground zero, perhaps because of its perceived capacity to influence the historical consciousness of the nation's young people. This kind of focus on the site of the curriculum as a battlefield for rival narratives of the nation is common to similar conflicts across the English-speaking world. ${ }^{18}$ Nietzsche also recognised the conflict that arises between the various perspectives on the past, though I read his argument as more positive about the need to deliberately pit one perspective against the other. To paraphrase Nietzsche's argument using Carratero's terms, an Enlightenment perspective alone leaves the student without narrative moorings, and their identity in limbo. An exclusively Romantic perspective leaves the student trapped in the limitations provided within the discourse of the past. Therein lies one of the central dilemmas facing school history. Is its purpose to offer students a form of historical literacy in which they are capable of critiquing representations of the past, or is its function to provide them with a source of identity? Can it do both successfully?

15 Sirkka Ahonen, "Post-conflict history education in Finland, South Africa and BosniaHerzegovina," Nordidactica: Journal of Humanities and Social Science Education 2013, no.1 (2013), 90-103. Taylor and Guyver, History wars.

16 Geoffrey Blainey, "Drawing up a balance sheet of our history,” Quadrant 37, no. 7-8 (1993): $10-15$.

17 Bain Attwood, Telling the truth about Aboriginal history (Crows Nest, NSW: Allen \& Unwin, 2005).

18 Jack. L. Granatstein, Who killed Canadian history? (Toronoto: HarperCollins, 1998). Gary B. Nash, Charlotte Crabtree, and Ross E. History on trial: Culture wars and the teaching of the past (New York: Alfred A, Knopf, 1998). Parkes, "Reading History“. Robert Phillips, History teaching, nationhood and the state: A study in educational politics (London: Cassell, 1998) 


\section{Remembering the Nation's Past}

Australia has experienced two decades of public and political struggle over the national narrative. ${ }^{19} \mathrm{~A}$ vision of history as the collective memory of the nation has led to this growing political interest in History curricula, and arguably motivated the establishment of a national curriculum with History as one of its cornerstone subjects ${ }^{20}$; and may also be responsible for on-going attempts at political interference in History education. ${ }^{21}$ Concerns over whose history is being taught in schools, ${ }^{22}$ continues to parallel anxieties over what the public knows about the nation's past ${ }^{23}$ often driven by survey research that expects an encyclopaedic knowledge of the past. The concern is compounded by the problem that both teachers and school students seem to find Australian history of little interest, ${ }^{24}$ and evidence that many teachers find themselves teaching History without the necessary historical knowledge and disciplinary training. ${ }^{25}$ Many studies internationally have concluded that subject-matter knowledge, including knowledge of the discipline and disciplinary modes of inquiry, is essential to good History teaching, ${ }^{26}$ but despite this, many History teachers often resort to didactic

19 Macintyre and Clark, history wars.

20 John Howard, "Unity vital in battle against terrorism," The Sydney Morning Herald, January 26, 2006: 11.

21 David Crowe, “Christopher Pyne tackles leftist 'bias' in classrooms," The Australian, January 10, 2014. http://www.theaustralian.com.au/national-affairs/policy/christopher-pyne-tackles-leftistbias-in-classrooms/story-fn59nlz9-1226798590821-mm-premium. Tony Taylor, “Howard's End: a narrative memoir of political contrivance, neoconservative ideology and the Australian history curriculum," Curriculum Journal 20, no. 4 (2009): 317-329. doi:10.1080/09585170903424765

22 Blainey, "our history“. Kevin Donnelly, “The black armband view of history,” Agora 32 no. 2 (1997) 15.

23 Paul Ashton, Jane Connors, Heather Goodall, Paula Hamilton, and Louelle McCarthy, "The Australians and the past at the University of Technology Sydney," Public History Review 8(2000): 168-173. Paul Ashton and Paula Hamilton, History at the crossroads (Ultimo, Sydney: Halstead Press, 2007).

24 Anna Clark, History's children: History wars in the classroom (Sydney: University of New South Wales Press, 2008).

25 Tony Taylor, The future of the past: Final report of the national inquiry into school history (Retrieved from Churchill, Vic. 2000).

26 Christine Counsell, "Disciplinary knowledge for all, the secondary history curriculum and history teachers' achievement," Curriculum Journal 22, no.2 (2012): 201-225. Linda S. Levstik and Keith C. Barton, eds., Researching history education: Theory, method, context (New York: Routledge, 2008). Samuel. S. Wineburg and Suzanne M. Wilson, "Subject-matter knowledge in the teaching of history," in Advances in Research on Teaching Vol.2, ed. Jere Brophy (Greenwich, Conn.: JAI Press, 1991). 
approaches when faced with managing student behaviour and what they perceive to be an over-whelming volume of curriculum content. ${ }^{27}$ The result seems to be that many teachers may resort to simply retelling narratives of the nation's past.

Given this situation, my colleagues in the HERMES Historical Cultures and History Education Research Network established at the University of Newcastle, decided to explore the stories pre-service History teachers tell when thinking about their nation's past; whether they embrace common narratives; what events they see as historically significant; how they deal with conflicting accounts; and the extent to which their narratives may have been influenced by school textbooks, popular film, or other historical media. The small pilot study was funded through the Faculty of Education and Arts' competitive Strategic Networks and Pilot Projects Grant Scheme. Our project 'borrowed' a methodology developed by Jocelyn Létourneau, ${ }^{28}$ in which participants were asked to "Please account for the history of Québec, as best you know or can remember it”. The outcomes of Létourneau's study refuted survey research and media reports that suggested Canadians had limited knowledge of their national history. Instead it was found that Québécois held detailed narratives about their collective past; and that some narratives appeared to be widely shared. Létourneau compared these commonly accepted narratives with official histories that participants would have encountered in school history textbooks, and determined that relationships did exist between these two sets of stories.

In the Australian context our research team asked a group of 97 pre-service History teachers (consisting of 27 males and 70 females, the overwhelming majority of whom identified as either or both European and Anglo-Celtic) to "Tell us the history of Australia in your own words.” This followed the latest refinements in Létourneau's methodology. The participants were given 45 minutes to write their personal account of the nation's past. They were instructed not to access the internet, and that we were interested exclusively in their accounts (not a perceived correct or incorrect answer to the question). The most common question in the various data collection sessions was "When should we start our narrative?"

Susanne. M. Wilson and Samuel S. Wineburg, "Peering at history through different lenses: The role of disciplinary perspectives in teaching history," Teachers College Record 89, no. 4 (1998): 525-539.

27 Keith C. Barton and Linda S. Levstik, "Why don't more History teachers engage students in interpretation?” Social Education 67, no. 6 (2003): 358-361.

28 Jocelyn Létourneau, "Remembering our past: An examination of the historical memory of young Québécois,” in To the past: History education, public memory, \& citizenship in Canada, ed. Ruth Sandwell (Toronto: University of Toronto Press, 2006). 
We refused to provide an answer to this question, inviting the participants to select the time period they thought relevant. Most started with reference to the ancient Aboriginal past, though a few were clearly 'Big historians', 29 and went far back into geological time when Gondwanaland was still part of the mega-continent Pangea. An even smaller number started with Federation and the official formation of the Australian nation. Once the narrative scripts were collected, they were analysed by the research team, seeking to identify any shared narratives and narrative templates that emerge from the data. These narratives were compared with the 'national narratives' evident in both the curriculum and popular media. We predicated the study on the assumption that our narratives of the past can be influenced by a variety of media forms. ${ }^{30}$ Our project was also predicated on a distinction between collective memory and "formal history". ${ }^{31}$ Formal history "views narratives as hypotheses against which evidence from archives, interviews, and other sources can be tested" whereas "collective memory often takes narratives as objects of dogmatic loyalty". ${ }^{32}$ Thus, the study was concerned with identifying shared narratives that underpin the collective memory or historical consciousness of pre-service History teachers.

Pre-service History teachers represent those individuals who, upon graduation, will be tasked with teaching the nation's past to future generations. A recent study of pre-service teachers at the University of Sydney found that alongside seeking to make a difference in the lives of young people, and work in a personally meaningful career, participants had made the decision to teach because they wanted to maintain a meaningful engagement with the subject area they were drawn to. ${ }^{33} \mathrm{~A}$ meaningful engagement with History suggests a strong interest in the past and the stories we hold about it. By developing an understanding of the narratives pre-service History teachers have appropriated, how they navigate competing accounts, and the influences on the formation of these narratives, we hoped to provide insights that night benefit the design of method courses in History teacher

29 Cynthia S. Brown, Big history: From the big bang to the present (New York: The New Press, 2012). David Christian," The case for “Big History”," Journal of World History 2, no. 2 (1991): 223-238.

30 Martin L. Davies, Historics: Why history dominates contemporary society (Abingdon: Routledge, 2006). Jerome de Groot, ed., Consuming history: Historians and heritage in contemporary popular culture (Abingdon: Routledge, 2009).

31 Maurice Halbwachs, The collective memory, trans. F. J. Ditter Jr and V. Y. Ditter (New York: Harper Collins Books, 1980).

32 James V. Wertsch and Zurab Karumidze, "Spinning the past: Russian and Georgian accounts of the war of August 2008," Memory Studies 2, no. 3 (2009): 379.

33 Jackie Manuel and John Hughes, “'It has always been my dream': exploring pre-service teachers' motivations for choosing to teach," Teacher Development: An international journal of teachers' professional development 10, no. 1(2006): 5-24. 
education programs. Further, our research sought to better understand how a group that are interested in the past (pre-service History teachers), engage with both collective memory and official history in their own narratives of the nation.

\section{Contours of the Narratives}

[Historiacal Significance, $n=97$ ]
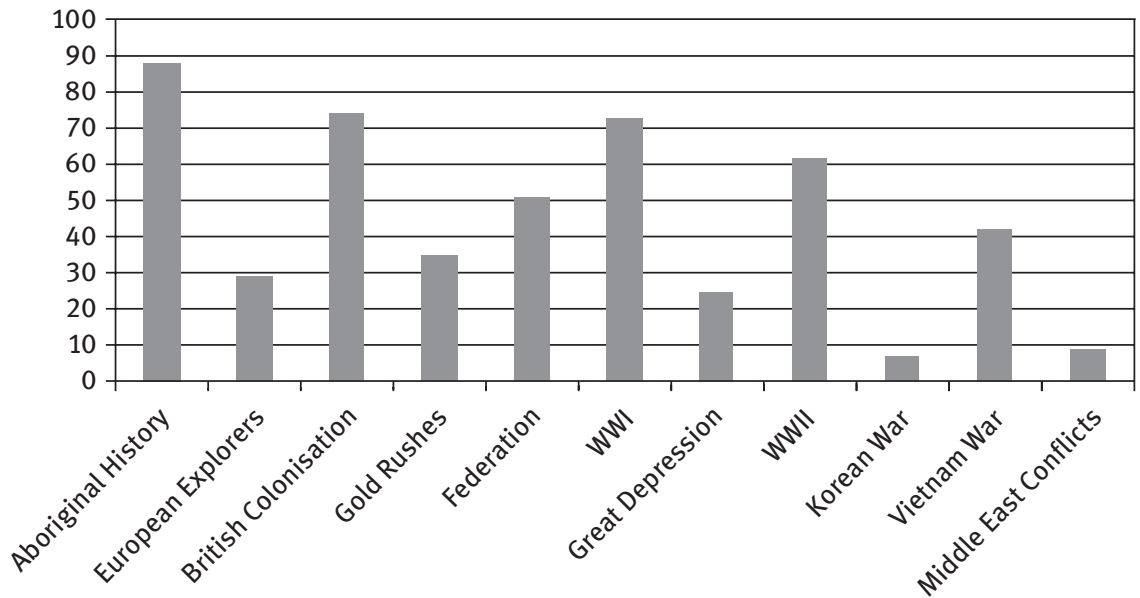

\section{Aboriginal History in the Narratives}

[ 88 of the 97 narratives referenced Aboriginal History ]

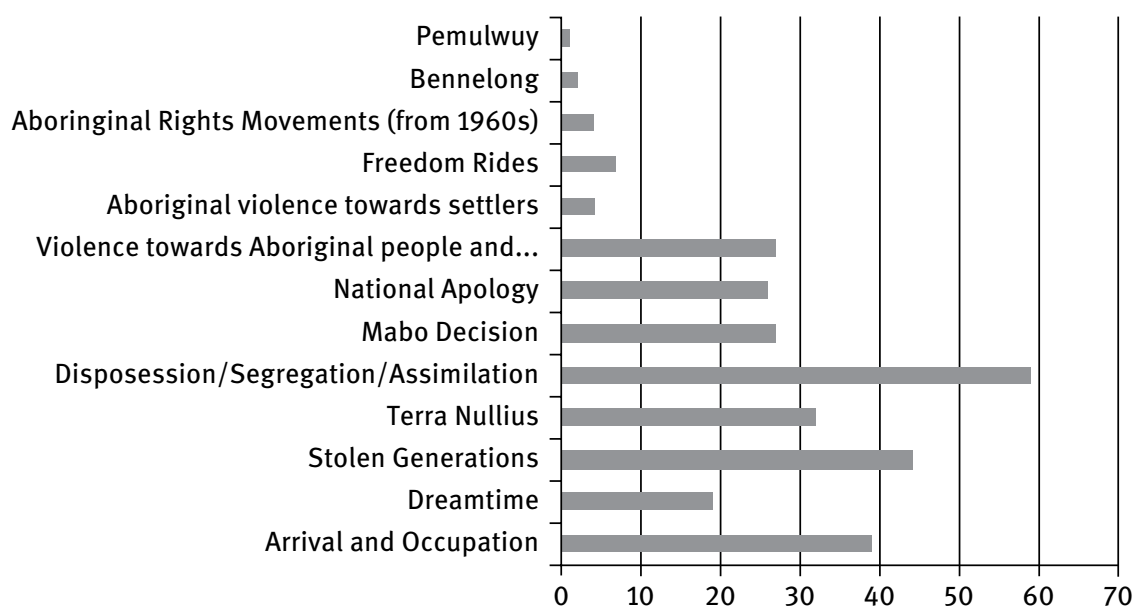


The first graph above reveals the 'contours' of the narratives the pre-service teachers told. Of the 97 participants from whom narratives were obtained, 88 discussed Aboriginal History, and 72 the British Colonisation of the Great Southern Land. 71 mentioned WWI, but only 29 discussed the European exploration of the continent, a topic that was once central to the curriculum. When Aboriginal History was discussed (as outlined in the second graph above), the overwhelming majority of the narratives concentrated on occupation, dispossession, segregation and assimilation during the colonial period; and a significant number focused on the stolen generations. Almost no one mentioned any Aboriginal resistance leader by name, and when they did, it was only Pemulwuy who entered the historical narratives they produced. The tone of the narratives was clearly negative towards the Europeans who had colonised the country, and Aboriginal people themselves were constructed as victims of European imperialism and oppression, with little room for agency. Statements appeared in their narratives such as the following:

- Aboriginal people had a spiritual connection with the land; their purpose for life was to care for the land. If they did not do this they had no purpose. Different to the white settlers' viewpoint on land and land use. They viewed land for expansion and industrial reasons. This caused many tensions between English settlers and Aboriginal people, the ignorance of the white settler cause Aboriginal people and their culture to be discriminated and devalued. Upon the settlement of the English, Australia was proclaimed as 'terra nullius' Meaning that there is no man's land, therefore the settlers were allowed to do whatever they wished to do with the land. [\#21]

- From an indigenous perspective, Australian history has been fraught with the annihilation of the Aboriginal race through to the assimilation in order for white settlers to gain dominance over the land and therefore resources. [\#40]

- The Aboriginal people, however, lived on Australia for many thousands of years, before being invaded by Europeans ... The lives of the Indigenous community were still being valued as inferior; Aboriginals could be killed without major concern. [\#37]

- For the aboriginal people this meant they were displaced from their land and many thousands were killed as europeans expanded. At the same time, guerrilla warfare began to take place between the aboriginals and the new settlers as both sides fought for the right to their land. [\#74]

- Australian history begins with the colonisation by the English and the inhabiting of the country prior to the colonisation by the Indigenous Australians, the Aboriginals. From then the history of our country is concerned around the treatment of the aboriginals by the white settlers. The policies of the time that were implemented controlled the treatment of these people. The Assimilation, 
Self-Determination, and were the policies brought in by the government of the time before the "White Australia" policy was introduced as an attempt to breed out the original owners of the land that was wrongly labelled “terra nullius". [\#50]

These narratives reflect a tendency towards a 'black armband' perspective on the past, particularly those sections highlighted in italics. This is evident when it is recognised that the narratives painted a one-sided picture of the colonial past, in which Europeans were the oppressors and Aboriginal people were victims without agency. Strangely, when faced with the story of Gallipoli, another controversial moment in debates over Australian history, the participants adopted what Blaineycalled the "three cheers view" of Australian history, ${ }^{34}$ as evident in the following excerpts (particularly the sections highlighted in italics):

- 1914-1918- WW1 Australia's first real chance to show its strength as its own country and show it is strong enough to be its own country. Gallipoli the great battle ground where we showed our true strength and Aussie spirit. [\#8]

- When World War One came around, Australia was still very much so a baby country, not valued very highly by others as it was still only so new. Australian's saw WWI as an opportunity to prove themselves, as a chance to be on the 'stage of the world' and show their abilities. [\#37]

- 1914 was the outbreak of the first world war, Australia participated in a bloody conflict on the Peninsular of Gallipoli in Turkey in April 1915 as part of the conjoined ANZAC forces (Australian and New Zealand Army Corps), this is retrospectively considered to be a baptism by fire of the newly formed nation. Solidifying what Australian meant as opposed to British. [\#97]

- Throughout the war the ANZACs engaged in British battles and garnered some level international influence due to its role. [\#39]

- Men were known to be strong and brave if they joined the war and thousands were shipped off overseas to fight battle in Europe. The first time Australia really made a mark on the world was in Gallipoli which could also be seen as Australia's biggest military fail. From here the idea of the ANZAC a brave solider who partakes in mate-ship and courageous acts was born. This idea has and still is imbedded in much of Australian society. [\#74]

34 Geoffrey Blainey, “There is a rival view, which I call the 'black armband' view: The John Latham memorial lecture," in Well may we say... The speeches that made Australia, ed. Sally Warhaft (Flinders Lane, Melbourne: Schwartz Publishing, 1993), 268. 


\section{Conclusion: The Education of History Teachers as Public Historians}

The paper by Zerwas reveals the intimate connection between public history and contemporary political discourse through the changing nature of a popular German history competition. Carratero's paper articulated the tension between Enlightenment and Romantic views of the past, and the particular problem this presents in postcolonial educational contexts. The Remembering Australia's Past study reported above suggests, I would argue, that the pre-service teachers whose stories of the nation we collected, have largely adopted popular discourses circulating in contemporary Australian society. They reflect, as Zerwas noted in reference to the German history competitions, public interest and the current state of political 'progress'. While on first glance the narratives of the colonial past may appear critical, the lack of agency attributed to Aboriginal people, and the virtual absence of Aboriginal resistance to the European colonisation, suggests a less well thought out engagement with the past. That for many of the participants the representation of Gallipoli rehearses the public rhetoric of this event as setting Australian on the world stage, further suggests the influence of popular discourse on the histories our pre-service teachers have readily accessible. This would suggest that much more work needs to be done with pre-service History teachers to help them explore the narratives they mobilise, how they have developed, and the perspectives from which they emerge. Following Nietzsche, I want to suggest the need to play between the tensions afforded by the Enlightenment and Romantic perspectives on the past identified by Carratero. I would argue that there is a need for our future history teachers as public historians to offer their students narratives which provide some form of temporal mooring or historical orientation in which to know themselves as historical beings. There is also need for critical perspectives that assist them to deconstruct the narratives 'truths' they have inherited and taken for granted. The tension between these approaches can be a productive one, and is arguably central to the project of public history in the classroom. 


\section{Literature cited}

Ahonen, Sirkka. Post-conflict history education in Finland, South Africa and BosniaHerzegovina. Nordidactica: Journal of Humanities and Social Science Education 2013, no.1 (2013): 90-103.

Ashton, Paul, Jane Connors, Heather Goodall, Paula Hamilton, and Louelle McCarthy. The Australians and the past at the University of Technology Sydney. Public History Review 8>(2000): 168-173.

Ashton, Paul and Paula Hamilton. History at the crossroads.Ultimo, Sydney: Halstead Press, 2007.

Attwood, Bain. Telling the truth about Aboriginal history. Crows Nest, NSW: Allen \& Unwin, 2005.

Barton, Keith C. and Linda S. Levstik. Why don't more History teachers engage students in interpretation? Social Education 67, no. 6 (2003): 358-361.

Blainey, Geoffrey. Drawing up a balance sheet of our history. Quadrant 37, no. 7-8 (1993): 10-15.

Blainey, Geoffrey. There is a rival view, which I call the 'black armband' view: The John Latham memorial lecture. In Well may we say... The speeches that made Australia, edited by Sally Warhaft, 267-278. Flinders Lane, Melbourne: Schwartz Publishing, 1993.

Brown, Cynthia S. Big history: From the big bang to the present.New York: The New Press, 2012. Christian, David. The case for "Big History". Journal of World History 2, no. 2 (1991): 223-238.

Clark, Anna. History's children: History wars in the classroom.Sydney: University of New South Wales Press, 2008.

Counsell, Christine. Disciplinary knowledge for all, the secondary history curriculum and history teachers' achievement. Curriculum Journal 22, no. 2 (2012): 201-225.

Crowe, David. Christopher Pyne tackles leftist 'bias' in classrooms. The Australian, January 10, 2014. http://www.theaustralian.com.au/national-affairs/policy/christopher-pyne-tacklesleftist-bias-in-classrooms/story-fn59nlz9-1226798590821-mm-premium.

Davies, Martin L. Historics: Why history dominates contemporary society. Abingdon: Routledge, 2006.

de Groot, Jerome, ed. Consuming history: Historians and heritage in contemporary popular culture. Abingdon: Routledge, 2009.

Donnelly, Kevin. The black armband view of history. Agora 32 no. 2 (1997) 15.

Giroux, Henry. Border pedagogy and the politics of postmodernism. In Postmodernism, postcolonialism and pedagogy, edited by Peter McLaren, 37-64.Sydney: James Nicholas Publishers, 1995.

Granatstein, Jack L. Who killed Canadian history? Toronoto: HarperCollins, 1998.

Halbwachs, Maurice. The collective memory. Translated by F. J. Ditter Jr and V. Y. Ditter.New York: Harper Collins Books, 1980.

Howard, John. Unity vital in battle against terrorism. The Sydney Morning Herald, January 26, 2006: 11.

Létourneau, Jocelyn. Remembering our past: An examination of the historical memory of young Québécois. In To the past: History education, public memory, \& citizenship in Canada, edited by Ruth Sandwell, 70-87.Toronto: University of Toronto Press, 2006.

Levstik, Linda S. and Keith C. Barton, eds. Researching history education: Theory, method, context.New York: Routledge, 2008.

Macintyre, Stuart and Anna Clark. The history wars. Melbourne: Melbourne University Press, 2003. 
Manuel, Jackie and John Hughes. 'It has always been my dream': exploring pre-service teachers' motivations for choosing to teach. Teacher Development: An international journal of teachers' professional development 10, no. 1 (2006): 5-24.

Nash, Gary B., Charlotte Crabtree, and Ross E. Dunn. History on trial: Culture wars and the teaching of the past.New York: Alfred A, Knopf, 1998.

Nietzsche, Friedrich. On the uses and disadvantages of history for life. Translated by R. teachers), engage with both collective memory and official history in their own J. Hollingdale. In Untimely meditations, edited by Daniel Breazeale, 57-123.Cambridge: Cambridge University Press, 1874/1983.

Parkes, Robert J. Reading History curriculum as postcolonial text: Towards a curricular response to the history wars in Australia and beyond. Curriculum Inquiry 37, no. 4 (2007): 383-400.

Parkes, Robert J. Teaching History as historiography: Engaging narrative diversity in the curriculum. International Journal of Historical Learning, Teaching and Research 8, no. 2 (2009): 118-132.

Parkes, Robert J. and Debra Donnelly. Changing conceptions of historical thinking in History education: An Australian case study. Revista Tempo e Argumento, Florianópolis 6, no. 11 (2014): 113-136.

Parkes, Robert J. and Heather Sharp. Nietzschean perspectives on representations of national history in Australian school textbooks: What should we do with Gallipoli? ENSAYOS: Revisita de la Facultad de Educación de Albacete 29, no. 1 (2014): 159-181.

Phillips, Robert. History teaching, nationhood and the state: A study in educational politics. London: Cassell, 1998.

Rüsen, Jörn. History: Narration - interpretation - orientation.New York: Berghahn Books, 2005.

Seixas, Peter. Schweigen! die Kinder! or does postmodern history have a place in the schools? In Knowing, teaching, and learning history: National and international perspectives, edited by Peter N. Stearns, Peter Seixas, and Sam Wineburg, 19-37.New York: New York University Press, 2000.

Sharpe, Jim. History from below. In New perspectives on historical writing, edited by Peter Burke, 24-41.Cambridge, UK: Polity Press, 1991.

Simon, Roger. I. The touch of the past: Remembrance, learning, and ethics.New York: Palgrave Macmillan, 2005.

Taylor, Tony. The future of the past: Final report of the national inquiry into school history. Retrieved from Churchill,Vic. 2000.

Taylor, Tony. Howard's End: a narrative memoir of political contrivance, neoconservative ideology and the Australian history curriculum. Curriculum Journal 20, no. 4 (2009): 317-329. doi:10.1080/09585170903424765

Taylor, Tony and Robert Guyver, eds. History wars in the classroom: Global perspectives. London: Information Age Publishing, 2011.

Wertsch, James V. Collective memory and narrative templates. Social Research: An International Quarterly, 75, no. 1(2008):133-156.

Wertsch, James V. and Zurab Karumidze. Spinning the past: Russian and Georgian accounts of the war of August 2008. Memory Studies 2, no. 3 (2009): 377-391.

Wilson, Susanne M. and Samuel S. Wineburg. Peering at history through different lenses: The role of disciplinary perspectives in teaching history. Teachers College Record 89, no. 4 (1998): 525-539.

Wineburg, Samuel. S. and Suzanne M. Wilson. Subject-matter knowledge in the teaching of history. In Advances in Research on Teaching Vol.2, edited by Jere Brophy, 305-347. Greenwich, Conn.: JAI Press, 1991. 
